Indonesian Journal of Cardiology

Indonesian J Cardiol 2018:39:120-127

pISSN: 0I 26-3773 / elSSN: 2620-4762

doi: $10.30701 /$ ijc.v39i3.820

\title{
Improvement of level MDA and SOD Using of Ganoderma Lucidum as Adjunctive Treatment for Statin Based Therapy in High Risk Patient Based on Framingham Score
}

\author{
Vitriyaturrida 1, M. Saifur Rohman 1, Dianggan Sargowo', \\ Dadang Hendrawan 1, Dr. Saiful Anwar2
}

I Department of Cardiology and Vascular Medicine, Faculty of Medicine, Universitas Brawijaya

2 General Hospital Malang

Correspondence:

Vitriyaturrida, MD

Department of Cardiology and Vascular Medicine

Faculty of Medicine,

Universitas Brawijaya

Dr. Saiful Anwar General

Hospital Malang

E-mail: vitriyaturrida@yahoo. com

\begin{abstract}
Background: It is well known from previous research on the importance of antioxidants to inhibit the progression of coronary heart disease in high-risk patients based on framingham scores. Statins are routinely administered in high-risk patients based on the Dyslipidemia 2016 ESC guidelines but the effects of adding Ganoderma are known to have antioxidant effects, in patients who have received statins. This study aims to assess the effect of antioxidants through measurement of SOD and MDA in patients given a combination of Ganoderma lucidum with statins.

Method: A total of 24 patients with high-risk patients based on the Framingham score $>20 \%$ were selected as sample of study. Patients with respondents who had never received statin therapy or ACEi or ARB or CCB or $\beta$ blocker, or did not routinely consume the drug for 2 weeks were excluded from this study. The addition of Ganoderma lucidum dose of $3 \times 250 \mathrm{mg}$ was added to statins as the first group and Ganoderma lucidum dose of $3 \times 250 \mathrm{mg}$ was added to the Statin combination of Angiotensin Converting Enzym inhibitors (ACE inhibitors) or Angiotensin Receptor Blockers (ARB) and or Calcium Channel Blockers (CCB) and or Beta blockers as second group for 90 days. SOD and MDA levels were measured before and after the administration of Ganoderma Lucidum with the ELISA method.

Result: After the administration of Ganoderma Lucidum with standard therapy, there was a decrease in MDA levels and an increase in SOD levels after 90 days in two groups.
\end{abstract}

Conclusion: The addition of Ganoderma Lucidum to standard therapy can reduce oxidant levels in high-risk patients based on framingham scores.

(Indonesian J Cardiol. 2018;39: I 20-127)'

Keywords: Superoxide-dismutase, Malondyaldehide, Stres oksidatif, Antioxidan, Ganoderma Lucidum, Statin 


\title{
Perbaikan Kadar Malondyaldehide dan Superoxide Dismutase Menggunakan Ganoderma Lucidum sebagai Terapi Adjuvan Berbasis Statin pada Pasien Resiko Tinggi Berdasarkan Skor Framingham
}

\author{
Vitriyaturrida ${ }^{1}$, M. Saifur Rohman 1, Dianggan Sargowo 1 , \\ Dadang Hendrawan ${ }^{1}$, Dr. Saiful Anwar ${ }^{2}$
}

\begin{abstract}
Abstrak
Latar belakang: Sudah banyak diketahui dari penelitian terdahulu tentang pentingnya antioksidan untuk menghambat progresifitas penyakit jantung koroner pada pasien resiko tinggi berdasarkan skor framingham. Selama ini statin diberikan secara rutin pada pasien Resiko Tinggi sesuai dengan guideline ESC dislipidemia 2016 namun belum diketahui efek penambahan Ganoderma yang diketahui mempunyai efek antioksidan, pada pasien yang sudah mendapat statin. Penelitian ini bertujuan untuk menilai efek antioksidan melalui pengukuran superoxide dismutase (SOD) dan Malondyaldehide (MDA) pada pasien yang diberikan kombinasi Ganoderma lucidum dengan statin.

Metode: Sebanyak 24 pasien dengan pasien resiko tinggi berdasarkan skor Framingham $>20 \%$ dipilih sebagai sampel penelitian. Pasien dengan responden yang tidak pernah mendapat terapi statin atau ACEi atau ARB atau CCB atau $\beta$ blocker, atau tidak rutin konsumsi obat tersebut selama 2 minggu dikeluarkan dari penelitian ini. Penambahan Ganoderma lucidum dosis 3x250 mg ditambahkan terhadap statin sebagai kelompok pertama dan Ganoderma lucidum dosis 3x250 mg ditambahkan terhadap Statin kombinasi Angiotensin Converting Enzym inhibitor (ACE inhibitor) atau Angiotensin Reseptor Blocker (ARB) dan atau Calcium Channel Blocker (CCB) dan atau Beta blocker sebagai kelompok kedua selama 90 hari. Kadar SOD dan MDA diukur sebelum dan sesudah pemberian Ganoderma Lucidum dengan metode ELISA. Hasil: Setelah pemberian Ganoderma Lucidum dengan terapi standart didapatkan penurunan kadar MDA dan peningkatan kadar SOD setelah 90 hari pada dua kelompok.

Kesimpulan: Penambahan Ganoderma Lucidum terhadap standart terapi dapat menurunkan kadar oksidan pada pasien resiko tinggi berdasarkan skor framingham.
\end{abstract}

(Indonesian J Cardiol. 2018;39:120-127)

Kata kunci: Superoxide-dismutase, Malondyaldehide, Stres oksidatif, Antioxidan, Ganoderma Lucidum, Statin

I Departemen Kardiologi dan Kedokteran Vaskular Fakultas kedokteran, Universitas Brawijaya

2 RSUD Malang

Korespondensi:

Vitriyaturrida, MD

Department of Cardiology and Vascular Medicine

Faculty of Medicine, Universitas Brawijaya

Dr. Saiful Anwar General Hospital Malang

E-mail: vitriyaturrida@yahoo.com

\section{Pendahuluan}

$\mathrm{P}$ enyakit jantung koroner (PJK) merupakan penyebab kematian terbanyak di dunia. World Health Organization (WHO) memperkirakan sekitar 20 juta kematian akibat penyakit kardiovaskuler pada tahun 2005.1 Menurut Survey Kesehatan Rumah Tangga (SKRT 2001), angka kematian di Indonesia dikarenakan penyakit jantung koroner mencapai 26,3\%. Riset Kesehatan Dasar (Riskesdas) 2007 menunjukkan bahwa prevalensi 
penyakit jantung koroner di Indonesia sekitar 9.2\% pada populasi usia lebih dari 15 tahun dan penyakit jantung iskemik memiliki proporsi $5.9 \% .^{1,2}$

Paparan kronis terhadap faktor risiko kardiovaskular dan stress oksidatif berperan besar terhadap mekanisme pertahanan endotelium vaskular, yang diikuti oleh disfungsi endotel dan hilangnya integritas endothelium, proliferasi sel otot halus dan migrasi, serta adhesi dan migrasi leukosit. Banyak bukti telah menunjuk ke disfungsi endotel sebagai salah satu perubahan patologis utama antara paparan faktor risiko kardiovaskular dan perkembangan penyakit kardiovaskular aterosklerotik. Statin adalah obat yang paling banyak dipelajari dalam pencegahan penyakit kardiovaskular. Sejumlah peneitian skala besar telah menunjukkan bahwa statin secara substansial mengurangi morbiditas dan mortalitas kardiovaskular di tingkat pencegahan primer dan sekunder, baik pada jenis kelamin maupun di semua kelompok umur. 3,4 Ganoderma lucidum memiliki zat aktif berupa $\beta$ - D Glucan, yang berfungsi sebagai antioksidan dengan mekanisme scavenging dari radikal bebas hidroksil radikal serta meningkatkan kadar superoxide dismutase (SOD) dan Catalase. ${ }^{5}$

Sudah banyak diketahui dari penelitian terdahulu tentang pentingnya antioksidan untuk menghambat progresifitas penyakit jantung koroner pada pasien resiko tinggi berdasarkan skor framingham. Selama ini statin diberikan secara rutin pada pasien Resiko Tinggi sesuai dengan guideline European Society of Cardiology (ESC) dislipidemia 2016 namun belum diketahui efek penambahan Ganoderma yang diketahui mempunyai efek antioksidan, pada pasien yang sudah mendapat statin. Penelitian ini bertujuan untuk menilai efek antioksidan melalui pengukuran SOD dan

Tabel 1. Karakteristik Dasar Pasien Risiko Tinggi yang Mendapatkan Penambahan Ganoderma lucidum dengan statin, Ganoderma lucidum dan Statin dan CCB/ACEi/ARB/ $\beta$ blocker

\begin{tabular}{|c|c|c|c|}
\hline \multirow[b]{2}{*}{ Karakteristik Dasar } & \multicolumn{2}{|c|}{ Kelompok } & \multirow[b]{2}{*}{$P$ value } \\
\hline & $\begin{array}{c}\text { PsP + Statin } \\
(\mathrm{n}=9)\end{array}$ & $\begin{array}{c}\mathrm{PsP}+\text { Statin }+ \text { CCB } / \text { ACEI } / \\
\text { ARB } / \beta \text { blocker } \\
(\mathrm{n}=15)\end{array}$ & \\
\hline $\begin{array}{l}\text { Jenis Kelamin } \\
\text { - Laki - laki } \\
\text { - Perempuan }\end{array}$ & $\begin{array}{c}6(25 \%) \\
3(12.5 \%)\end{array}$ & $\begin{array}{l}3(12.5 \%) \\
12(50 \%)\end{array}$ & 0.036 \\
\hline Usia & $68.00 \pm 6.00$ & $62.53 \pm 10.99$ & 0.186 \\
\hline $\mathrm{BB}$ & $64.11 \pm 13.11$ & $67.13 \pm 5.91$ & 0.529 \\
\hline TB & $165.78 \pm 6.04$ & $155.53 \pm 6.97$ & 0.001 \\
\hline Indeks Massa Tubuh (IMT) & $23.89 \pm 4.34$ & $27.80 \pm 3.41$ & 0.052 \\
\hline $\begin{array}{l}\text { Hipertensi } \\
\text { - Hipertensi } \\
\text { - Tidak Hipertensi }\end{array}$ & $\begin{array}{l}5(20.8 \%) \\
4(16.7 \%)\end{array}$ & $\begin{array}{c}15(62.5 \%) \\
0(0 \%)\end{array}$ & 0.012 \\
\hline $\begin{array}{l}\text { Displidemia } \\
\text { - Dislipidemia } \\
\text { - Tidak Dislipidemia }\end{array}$ & $\begin{array}{l}5(20.8 \%) \\
4(16.7 \%)\end{array}$ & $\begin{array}{l}7(29.2 \%) \\
8(33.3 \%)\end{array}$ & 1.000 \\
\hline $\begin{array}{l}\text { Diabetes melitus } \\
\text { - DM } \\
\text { - Tidak DM }\end{array}$ & $\begin{array}{c}1(4.2 \%) \\
8(33.3 \%)\end{array}$ & $\begin{array}{c}5(20.8 \%) \\
10(41.7 \%)\end{array}$ & 0.351 \\
\hline Kolesterol total & $193.33 \pm 45.52$ & $208.67 \pm 49.03$ & 0.455 \\
\hline HDL & $44.78 \pm 12.67$ & $52.40 \pm 19.99$ & 0.318 \\
\hline LDL & $113.78 \pm 36.52$ & $123.00 \pm 45.25$ & 0.610 \\
\hline Trigliserida & $128.22 \pm 55.04$ & $131.53 \pm 49.94$ & 0.881 \\
\hline GDP & $122.67 \pm 59.03$ & $102.13 \pm 43.16$ & 0.336 \\
\hline
\end{tabular}

$\mathrm{BB}=$ berat badan; $\mathrm{TB}=$ tinggi badan; $\mathrm{HDL}=$ High density lipoprotein; $\mathrm{LDL}=$ Low density lipoprotein; $\mathrm{GDP}=$ gula darah puasa; PsP = Polysaccharide Peptide 
Indonesian Journal of Cardiology

Tabel 2. Perbedaan Kadar SOD Sebelum dan Sesudah Penambahan Ganoderma Lucidum pada Tiap Kelompok

\begin{tabular}{lccc}
\hline \multicolumn{1}{c}{ Kelompok } & Pre & Post & P value \\
\hline Ganoderma Lucidum + Statin & $3.39 \pm 0.47$ & $5.88 \pm 3.31$ & 0.039 \\
Ganoderma lucidum + Statin + CCB/ACEI/ARB/ $\beta$ blocker & $3.57 \pm 0.88$ & $4.76 \pm 3.52$ & 0.224 \\
\hline
\end{tabular}

$\mathrm{CCB}=$ Calcium channel blocker; $\mathrm{ACE}=$ Angiotensin converting enzym inhibitor; $\mathrm{ARB}=$ Angiotensin reseptor blocker; $\beta$ blocker $=$ beta blocker

Malondyaldehide (MDA) pada pasien yang diberikan kombinasi Ganoderma lucidum dengan statin.

\section{Metode}

Penelitian ini merupakan penelitian Kohort Retrospektif dengan menggunakan metode pretest dan postest desain, untuk mengetahui pengaruh pemberian peptida polisakarida (PSP) Ganoderma lucidum untuk pencegahan primer pada pasien Resiko Tinggi berdasarkan skor Framingham dari studi yang telah dilakukan sebelumnya oleh Prof. dr. Djanggan Sargowo, Sp.PD, SP.JP(K) "Pengembangan Potensi Peptida Polisakarida (Ganoderma Lucidum) Sebagai Antioksidan Dan Antiinflamasi Dalam Upaya Penanganan Komprehensif Penyakit Kardiovaskuler" yang telah lolos uji Ethical Clearence dari komisi etik penelitian kesehatan RSUD Dr.Saiful Anwar Malang dengan nomor: 400/79/K.3/302/2015.

Kriteria inklusi pada penelitian ini adalah semua pasien risiko tinggi menurut skor Framingham yang mendapat terapi statin saja minimal 2 minggu sebagai kelompok pertama, dan pasien yang mendapat terapi statin minimal 2 minggu dengan terapi ACEi atau ARB dan atau CCB dan atau $\beta$ blocker sebagai kelompok kedua, serta tidak pernah didapatkan kejadian kardiovaskular dalam kurun waktu tersebut. Kriteria eksklusi adalah responden yang tidak pernah mendapat terapi statin atau $\mathrm{ACEi}$ atau $\mathrm{ARB}$ atau $\mathrm{CCB}$ atau $\beta$ blocker, atau tidak rutin konsumsi obat tersebut selama 2 minggu.

Kadar MDA diperkirakan oleh reaksi thiobarbituric acid (TBA). Menggunakan asam trikloroasetat, protein diendapkan dari $0,2 \mathrm{~mL}$ serum, dan protein yang diendapkan diinkubasi dengan reagen TBA dalam rendaman air mendidih selama 60 menit. Kompleks berwarna yang terjadi didinginkan ke suhu ruang dan diukur dengan menggunakan spektrofotometer pada 532 nm. Untuk estimasi MDA, 1,1,3,3- tetraethoxypropane (1 $\mu \mathrm{mol} / \mathrm{L}$ ) digunakan sebagai standar. Untuk pengukuran SOD, seluruh darah di hemolisis dan SOD diekstraksi dengan suatu etanol / kloroform campuran. SOD ditentukan dalam diekstraksi hemolysate dengan koreksi untuk perubahan volume selama proses ekstraksi. Aktivitas SOD diungkapkan sebagai unit aktivitas per mg hemoglobin. Primary end point adalah perbaikan kadar MDA dan SOD pre dan post test setelah ditambahkan Ganoderma lucidum pada kedua kelompok. Secondary end point adalah mengetahui korelasi efek Ganoderma lucidum dengan statin sebagai antioksidan dengan efek hipokolesterolemia. 6,7,8

Variabel numerik disajikan sebagai mean \pm SD. Variabel kategorik disajikan sebagai frekuensi dan persentase. Uji komparatif 2 variabel numerik tidak berpasangan dilakukan dengan menggunakan uji Mann Whitney. Uji komparatif 2 variabel variabel kategorik dilakukan dengan menggunakan uji Chi square atau uji Fisher. Uji komparatif 2 variabel numerik berpasangan dengan menggunakan paired t-test. Nilai $\mathrm{p} \leq 0.05$ dianggap signifikan secara statistik.

\section{Hasil}

Penelitian ini melibatkan 68 pasien risiko tinggi dari studi yang telah dilakukan sebelumnya oleh Prof. dr. Djanggan Sargowo, Sp.PD, SP.JP(K) "Pengembangan

Tabel 3. Perbedaan Kadar MDA Sebelum dan Sesudah Penambahan Ganoderma Lucidum pada Tiap Kelompok

\begin{tabular}{lccc}
\hline \multicolumn{1}{c}{ Kelompok } & Pre & Post & P value \\
\hline Ganoderma Lucidum + Statin & $99.26 \pm 30.90$ & $65.13 \pm 29.81$ & 0.047 \\
Ganoderma lucidum + Statin + CCB/ACEI/ARB/ $\beta$ blocker & $102.81 \pm 38.97$ & $55.20 \pm 38.97$ & 0.002 \\
\hline
\end{tabular}

$\mathrm{CCB}=$ Calcium channel blocker; $\mathrm{ACE}=$ Angiotensin converting enzym inhibitor; $\mathrm{ARB}=$ Angiotensin reseptor blocker; $\beta$ blocker $=$ beta blocker 
Potensi Peptida Polisakarida (Ganoderma Lucidum) Sebagai Antioksidan Dan Antiinflamasi Dalam Upaya Penanganan Komprehensif Penyakit Kardiovaskuler". Yang mendapatkan terapi kombinasi Ganoderma dengan statin sebanyak 8 pasien, kombinasi Ganoderma lucidum dan Statin dan CCB/ACEi/ARB/ $\beta$ blocker sebanyak 15 pasien sedangkan sebanyak 31 pasien diekslusi karena tidak menggunakan statin, sedangkan 13 pasien lainnya dieksklusi dari penelitian karena kepatuhan minum obat tidak rutin.

Karakteristik pasien risiko tinggi yang mendapatkan Ganoderma lucidum dengan statin dan Ganoderma lucidum dengan Statin dan CCB/ACEi/ARB/ $\beta$ blocker pada tabel 5.1. Dari tabel tersebut diketahui jumlah pasien perempuan lebih banyak dibandingkan laki-laki. Dari 24 sampel, 15 sampel berjenis kelamin perempuan. Prosentase jenis kelamin perempuan tinggi pada kelompok kedua yaitu prosentase $12 \%$ dari sampel penelitian. Sedangkan pada kelompok pertama justru diperoleh jenis kelamin laki-laki lebih banyak dengan prosentase sebesar $25 \%$. Secara statistik terdapat hubungan signifikan antara variable jenis kelamin dengan pembagian kelompok pada studi ini $(\mathrm{p}=0,036)$.

Demikian pula pada analisa statistik terhadap variabel tinggi badan dan riwayat hipertensi diperoleh hasil yang signifikan $(\mathrm{p}<0,05)$. Berdasarkan uji homogenitas dari masing-masing data, diketahui bahwa variabel TB pada masing-masing kelompok memiliki variasi populasi yang sama. Sedangkan berdasarkan uji independent t-test diketahui bahwa paling tidak terdapat dua rata-rata nilai TB yang berbeda antar kelompok ( $p$ $<0,05)$. Rata-rata tinggi badan pada kelompok pertama lebih tinggi dibandingkan pada kelompok kedua. Sedangkan riwayat hipertensi terbanyak diperoleh pada kelompok kedua.

Berdasarkan uji homogenitas dari masing-masing data, diketahui bahwa variabel usia pada masingmasing kelompok memiliki variasi populasi yang sama. Sedangkan berdasarkan uji independent t-test diketahui bahwa rata-rata usia, berdasarkan kelompok adalah sama dengan nilai signifikasi $\mathrm{p}=0,186(\mathrm{p}>0,05)$. Pada variabel berat badan dan indeks massa tubuh, hasil rata-rata berat badan dan IMT berdasarkan kelompok adalah sama, dengan nilai signifikansi $\mathrm{p}=0.529$, dan $\mathrm{p}$ $=0.052(\mathrm{p}>0,05)$. Begitu pula dari karakteristik dasar berdasarkan uji independent t-test diketahui bahwa kadar kolesterol total, HDL, LDL, trigliserida, dan gula darah puasa pada masing kelompok adalah sama dengan nilai signifikasi $\mathrm{p}>0,05$.

Dilakukan uji paired $t$-Test pada kedua kelompok dengan hasil analisa menunjukkan terdapat perbedaan yang signifikan antara kadar MDA sebelum dan setelah penambahan Ganoderma lucidum pada kelompok yang mendapatkan statin $\mathrm{p}=0.039(\mathrm{p}<0.05)$ dan pada kelompok kedua pasien yang mendapatkan statin dengan $\mathrm{CCB} / \mathrm{ACEi} / \mathrm{ARB} / \beta$ blocker selama 90 hari terdapat peningkatan kadar SOD meskipun tidak signifikan $p=0.224 \quad(p>0.05)$, ditunjukkan pada tabel 5.2. Sedangkan pada kedua kelompok yang mendapat penambahan Ganoderma lucidum dengan statin dan Ganoderma lucidum dengan statin dan atau CCB/ ACEi/ARB $/ \beta$ blocker didapatkan perbedaan yang signifikan terhadap kadar MDA sebelum dan sesudah penambahan Ganoderma lucidum dengan nilai signifikansi berurutan $\mathrm{p}=0,047$ dan $\mathrm{p}=0.002(\mathrm{P}<0,05)$ ditunjukkan pada tabel 5.3.

Berdasarkan uji korelasi Pearson menunjukkan terdapat hubungan pada kelompok statin, terdapat hubungan

Tabel 4. Hubungan Dislipidemia dengan Perubahan Kadar SOD dan MDA

\begin{tabular}{lcccc}
\hline \multirow{2}{*}{ Variabel } & \multirow{2}{*}{ Mean $\pm \mathrm{SD}$} & \multicolumn{2}{c}{ Signifikansi } & \multirow{2}{*}{ Koef Korelasi (r) } \\
\cline { 3 - 4 } & & $\Delta \mathrm{MDA}$ & $\Delta \mathrm{SOD}$ & \\
\hline$\Delta \mathrm{HDL}$ & $-12.38 \pm 14.70$ & 0.632 & 0.969 & Tidak ada korelasi \\
$\Delta \mathrm{LDL}$ & $-1.29 \pm 31.80$ & 0.486 & 0.005 & 0.553 (korelasi cukup kuat) \\
$\Delta \mathrm{TG}$ & $15.38 \pm 76.44$ & 0.840 & 0.660 & Tidak ada korelasi \\
$\Delta$ KolesTotal & $-14.13 \pm 40.18$ & 0.494 & 0.011 & 0.508 (korelasi cukup kuat) \\
$\Delta$ SOD & $1.67 \pm 3.40$ & 0.992 & - & -0.002 \\
$\Delta$ MDA & $-42.56 \pm 47.12$ & - & 0.992 & -0.002 \\
\hline
\end{tabular}

$\triangle \mathrm{HDL}=$ delta high density lipoprotein; $\triangle \mathrm{LDL}=$ delta low density lipoprotein; $\Delta \mathrm{TG}=$ delta trigliserida; $\Delta \mathrm{SOD}$ = delta superoxyde dismutase; $\triangle \mathrm{MDA}=$ delta malondyaldehide 
antara (tabel 5.4) perubahan kolesterol total ( $\triangle$ Kolesterol Total) dengan perubahan kadar SOD $(\triangle \mathrm{SOD})$, dengan koef korelasi (r) sebesar 0.508 (hubungan positif dan cukup kuat). Selain itu terdapat hubungan $\triangle \mathrm{LDL}$ dengan $\triangle \mathrm{SOD}$ dengan koefisien korelasi ( $\mathrm{r}$ ) sebesar 0.553 (hubungan positif dan cukup kuat).

\section{Diskusi}

Pada kelompok pertama didapatkan sebanyak 9 pasien yang mendapatkan terapi kombinasi Ganoderma lucidum dan Statin, didapatkan perbedaan yang signifikan antara kadar SOD dan MDA sebelum dan sesudah penambahan Ganoderma lucidum (pre dan post test). Selain efek penurun kolesterol statin, beberapa penelitian telah menunjukkan bahwa efek menguntungkan statin mungkin karena efek pleiotropik. Asam mevalonat, produk (HMG$\mathrm{CoA}$ ) reaksi reduktase, adalah prekursor tidak hanya kolesterol tetapi juga nonsteroid senyawa isoprenoid. Diperkirakan bahwa banyak dari efek pleiotropic dimediasi oleh penghambatan isoprenoid, seperti protein pengikat GTP, yang mungkin berfungsi sebagai perlekatan lipid untuk sinyal intraseluler. ${ }^{13,14}$ Meskipun penelitian sebelumnya Vasankari et all memberikan hasil belum jelas sepenuhnya pada efek statin pada status antioksidan dan penelitian terbaru menunjukkan bahwa statin meningkatkan status antioksidan, termasuk vitamin $\mathrm{E}$ dan serum aktivitas PON1, enzim antioksidan yang terkait dengan kolesterol HDL. Peningkatan adjuvan antioksidan dalam pengobatan statin pasien telah disarankan untuk mengurangi stres oksidatif dan meningkatkan antioksidan. 13, 15

Ada dua jenis utama antioksidan pada PSP Ganoderma lucidum. Antioksidan utama memiliki sifat seperti pemecah rantai dan radikal bebas. Efek Antioksidan sekunder atau preventif mampu mendeaktivasi logam, menghambat atau memecah hidroperoksida lipid, dan menginduksi regenerasi antioksidan primer. Peptida Ganoderma lucidum diduga dapat meningkatkan aktivitas SOD dan CAT. ${ }^{9}$ Dari penelitian Smina dan kolega menunjukkan bahwa triterpen yang diekstraksi dari G. lucidum memiliki anti oksidatif in vitro dan dapat mengurangi kerusakan oksidatif dengan scavenging langsung radikal bebas yang dihasilkan di sel. Selain itu, pemberian triterpen pada tikus meningkatkan aktivitas enzim antioksidan dan mengurangi kerusakan
DNA oksidatif akibat oksidasi pada splenosit tikus. Kemampuan triterpen untuk scavenge radikal bebas dan meningkatkan enzim antioksidan bawaan menunjukkan bahwa triterpen adalah anti oksidan yang sangat efisien. 10,11

Sedangkan dari penelitian oleh Deng Pan et.al, komposisi proteoglikan yang didominasi oleh novel proteoglikan Ganoderma lucidum yang disebut dengan Fudan Yeuyang (FYGL) merupakan antioksidan yang efektif disebabkan karena adanya properti unik redoks dan struktur kimianya. Penelitian sebelumnya menunjukkan bahwa beberapa senyawa seperti chitin dan L-carrageenan oligosaccharida dapat menghambat oksidasi LDL dan secara keseluruhan memberikan dampak yang positif pada metabolisme lemak. Senyawa tersebut dapat berfungsi sebagai pemecah rantai donor elektron atau chelating metal ion atau sebagai detoksifikan pada produk perantara oksigen reaktif peroksidasi lipid yang juga mendapatkan hasil yang sama pada penelitian oleh Den Pang et.al, sehingga peneliti menyimpulkan bahwa FYGL memiliki peranan protektif pada kerusakan oksidatif disebabkan karena memiliki peranan protektif pada kerusakan oksidatif disebabkan karena didapatkan potensi antioksidan pada proteoglikan Ganoderma lucidum. ${ }^{11}$

Penelitian lain yang dilakukan R. Sartarelli dkk 2009 dan You dkk 2000 mengonfirmasi bahwa ekstrak ganoderma lucidum mempunyai efek antioksidan yang kuat. Pada penelitian yang dilakukan oleh Casieri dkk pada mencit ditemukan bahwa pemberian beta-glukan akan meningkatkan densitas kapiler miokardium, VEGF, kadar protein dectin-1, asetilasi histon $\mathrm{H} 4, \mathrm{MnSOD}$, kadar p53 dan Parkin, selain itu akan menurunkan kadar stress oksidatif, caspase-3, HIF1-alfa, pAkt/Akt, pSTAT3/STAT3 dan pNF-kB/NF-kB. ${ }^{12}$

Selanjutnya untuk peningkatan pertahanan antioksidan vaskular ,statin melemahkan efek prooksidan Ang II dengan down-regulating Ekspresi AT1R, sementara efek scavenger langsung pada superoksid juga punya telah dilaporkan. Selain itu, statin mengurangi aktivitas NADPH oksidase yang merupakan sumber ROS utama di dinding pembuluh darah. Ini dimediasi oleh penghambatan isoprenoid yang dapat dihancurkan oleh pembentukan mivalonat dan translokasi membran protein GTP kecil Rac1. ${ }^{16}$ Efek ini pada NADPH oksidase dapat menurunkan ROS stres oksidatif vaskular dan melindungi $\mathrm{BH} 4$ dari katabolisme oksidatif, 
sehingga secara tidak langsung meningkatkan kopling eNOSDi dalam konteks, data kami memberikan bukti bahwa NADPH oksidase dapat mewakili mekanisme penting yang memunculkan oksidasi LDL. Mengingat peran sentral dimainkan oleh LDL teroksidasi di atherogenesis, efek antioksidan yang telah ditetapkan dari statin menjadi efek kedua. ${ }^{17,20}$

Selain membalikkan efek penghambatan teroksidasi LDL pada eNOS, statin juga memiliki efek antioksidan langsung LDL secara in vitro dan ex vivo. Statin telah ditampilkan secara in vitro dan pada model binatang untuk mengurangi beberapa NADPH subunit oksidase seperti rac 1, gp22phox, dan gp91phox (inti utama oksidase NADPH), bahwa efek tersebut mungkin relevan dalam properti antioksidan dari statin. Hal yang sama ditemukan dalam penelitian kami dimana $\triangle$ LDL dengan $\triangle$ SOD dengan koef korelasi (r) sebesar 0.553 (hubungan positif dan cukup kuat (tabel 5.4). ${ }^{13}, 15,17$

Pada kelompok kedua yang mendapatkan kombinasi dari Ganoderma lucidum dan Statin dan CCB/ACEi/ $\mathrm{ARB} / \Omega$ blocker juga didapatkan perbedaan yang signifikan antara kadar MDA (pre dan post test) sehingga hasil penelitian ini mendukung hipotesis yang telah dirumuskan. Tetapi tidak didapatkan perbedaan yang signifikan antara kadar SOD (pre dan post test). Studi sebelumnya Sun et all menunjukkan bahwa atorvastatin mengembalikan aktivitas NO sintase pada endotel melalui downregulation dari ekspresi caveolin-1 dan meningkatkan konsentrasi NO dan aktivitas GPx dan SOD. Penelitian Broncel et al terjadi peningkatan yang signifikan dari aktivitas enzim antioksidan yaitu CAT, SOD dan GSH-Px selama pengobatan atorvastatin dan simvastatin selama 4-12 minggu pada pasien dislipidemia. ${ }^{18,19,} 20$

\section{Kesimpulan}

Penambahan Ganoderma Lucidum terhadap standart terapi dapat menurunkan kadar oksidan pada pasien resiko tinggi berdasarkan skor framingham.

\section{Daftar Singkatan}

$\mathrm{HDL}=$ High density lipoprotein

$\mathrm{LDL}=$ Low density lipoprotein

$\mathrm{TG}=$ Trigliserida

$\mathrm{GDP}=$ gula darah puasa
$\mathrm{SOD}=$ Superoxyde Dismutase

MDA = Malondyaldehide

$\mathrm{CCB}=$ Calcium channel blocker

$\mathrm{ACE}=$ Angiotensin converting enzym inhibitor

$\mathrm{ARB}=$ Angiotensin reseptor blocker

$\beta$ blocker $=$ beta blocker

\section{Persetujuan Etik}

Keterangan kelaikan etik pelaksanaan penelitian (ethical clearence) RSUD dr. Saiful Anwar Malang No: 400/79/K.3/302/2015

\section{Persetujuan untuk Publikasi}

Semua pihak sudah menyetujui publikasi naskah ini.

\section{Konflik kepentingan}

Tidak ada konflik kepentingan dalam penelitian ini.

\section{Pendanaan}

Hibah penelitian SPIP Fakultas Kedokteran Universtas Brawijaya periode 2015.

\section{Daftar Pustaka}

1. Institute of Medicine Committee on Preventing the Global Epidemic of Cardiovascular Disease: Meeting the Challenges in Developing C. The National Academies Collection: Reports funded by National Institutes of Health. In: Fuster V, Kelly BB, editors. Promoting Cardiovascular Health in the Developing World: A Critical Challenge to Achieve Global Health. Washington (DC): National Academies Press (US) National Academy of Sciences.; 2010.

2. Delima LM, Hadi Siswoyo. Prevalensi dan faktor determinan penyakit jantung di Indonesia Bul Penelit Kesehat. 2009;37:: 142 - 15.

3. Gui T, Shimokado A, Sun Y, Akasaka T, Muragaki Y. Diverse roles of macrophages in atherosclerosis: from inflammatory biology to biomarker discovery. Mediators of inflammation. 2012;2012:693083

4. Chen SN, Nan FH, Chen S, Wu JF, Lu CL, Soni MG. Safety assessment of mushroom beta-glucan: 
subchronic toxicity in rodents and mutagenicity studies. Food and chemical toxicology : an international journal published for the British Industrial Biological Research Association. 2011;49(11):2890-8.

5. Wang XC, Xi RJ, Li Y, Wang DM, Yao YJ. The species identity of the widely cultivated Ganoderma, 'G. lucidum' (Ling-zhi), in China. PloS one. 2012;7(7):e40857

6. Shirley R, Ord ENJ, Work LM. Oxidative Stress and the Use of Antioxidants in Stroke. Antioxidants. 2014;3(3):472-501.

7. Pashkow FJ. Oxidative Stress and Inflammation in Heart Disease: Do Antioxidants Have a Role in Treatment and/or Prevention? International journal of inflammation. 2011;2011:514623.

8. Smina TP, Mathew J, Janardhanan KK, Devasagayam TP. Antioxidant activity and toxicity profile of total triterpenes isolated from Ganoderma lucidum (Fr.) P. Karst occurring in South India. Environmental toxicology and pharmacology. 2011;32(3):43846.

9. Smina TP, Mathew J, Janardhanan KK, Devasagayam TP. Antioxidant activity and toxicity profile of total triterpenes isolated from Ganoderma lucidum (Fr.) P. Karst occurring in South India. Environmental toxicology and pharmacology. 2011;32(3):43846.

10. Pan D, Zhang D, Wu J, Chen C, Xu Z, Yang H, et al. Antidiabetic, antihyperlipidemic and antioxidant activities of a novel proteoglycan from ganoderma lucidum fruiting bodies on $\mathrm{db} / \mathrm{db}$ mice and the possible mechanism. PloS one. 2013;8(7):e68332.

11. Lee J LP. Lipoproteins and the Endothelium: Past, Present and Future Hellenic journal of cardiology : $\mathrm{HJC}=$ Hellenike kardiologike epitheorese. 206;47:158-9.

12. Casieri V, Matteucci M, Cavallini, et.al. Long term intake of pasta containing barley (1-3) beta-D-glucan increases neovascularization-mediated cardioprotection through endothelial upregulation of vascular endothelial growth factor and parkin. Scientific Reports, 2017:13424

13. Taylor F, Huffman MD, Macedo AF, et al. Statins for the primary prevention of cardiovascular disease. Cochrane Database Syst Rev 2013; (1): CD004816.

14. Mihaylova B, Emberson J, Blackwell L, et al. The effects of lowering LDL cholesterol with statin ther- apy in people at low risk of vascular disease: meta-analysis of individual data from 27 randomised trials. Lancet 2012; 380(9841): 581-590.

15. Taylor F, Huffman MD, Macedo A, Moore THM, Burke M, Davey Smith G, Ward K, Ebrahim S. Statins for the primary prevention of cardiovascular disease. 31 January 2013

16. Wilck $\mathrm{N}$ and Ludwig A. Targeting the ubiquitin-proteasome system in atherosclerosis: Status quo, Challenges and perspectives. Antioxidants \& redox signaling volume 21,number 17,2014

17. Alexios S. Antonopoulos, Marios Margaritis, Regent Lee, Keith Channon, and Charalambos Antoniades. Statins as Anti-Inflammatory Agents in Atherogenesis: Molecular Mechanisms and Lessons from the Recent Clinical Trials. Current Pharmaceutical Design, 2012, 18, 1519-153

18. Wilck $\mathrm{N}$ and Ludwig A. Targeting the ubiquitin-proteasome system in atherosclerosis: Status quo, Challenges and perspectives. Antioxidants \& redox signaling volume 21, number 17,2014

19. Alexios S. Antonopoulos, Marios Margaritis, Regent Lee, Keith Channon, and Charalambos Antoniades. Statins as Anti-Inflammatory Agents in Atherogenesis: Molecular Mechanisms and Lessons from the Recent Clinical Trials. Current Pharmaceutical Design, 2012, 18, 1519-153

20. Vasankari T, Ahotupa M, Viikari J, Nuotio I, Strandberg T, Vanhanen H, Gylling H, Miettinen T, Tikkanen MJ. Effect of 12-month statin therapy on antioxidant potential of LDL and serum antioxidant vitamin concentrations. Ann Med 2004;36: 618-622. 